
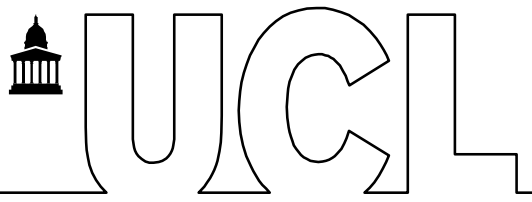

Shrubsole, C; Ridley, I; Biddulph, P; Milner, J; Vardoulakis, S; Ucci, M; Wilkinson, P; (2012) Indoor PM2.5 exposure in London's domestic stock: Modelling current and future exposures following energy efficient refurbishment. ATMOSPHERIC ENVIRONMENT, 62 336 - 343. 10.1016/j.atmosenv.2012.08.047. Downloaded from UCL Discovery: http://discovery.ucl.ac.uk/1370062

\title{
ARTICLE
}

\section{Indoor PM2.5 exposure in London's domestic stock: modeling current and future exposures following energy efficient refurbishment.}

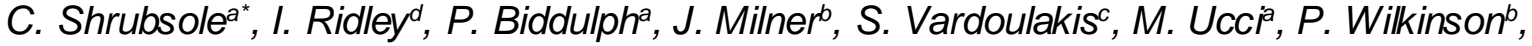 \\ Z. Chalabib and M. Davies ${ }^{a}$ \\ ${ }^{a}$ Complex Built Environment Systems Group, Bartlett School of Graduate Studies, University \\ College London, Central House, 14 Upper Woburn Place, London, WC1H ONN, UK. \\ ${ }^{b}$ Department of Social \& Environmental Health Research, London School of Hygiene \& \\ Tropical Medicine, 15-17 Tavistock Place, London WC1H 9SH, UK. \\ ${ }^{c}$ Centre for Radiation, Chemical \& Environmental Hazards, Health Protection Agency, \\ Chilton, Oxon OX11 ORQ, UK \\ 'School of Property, Construction and Project Management, RMIT University, GPO \\ box 2476, Melbourne, VIC 3001, Australia.
}

\begin{abstract}
Simulations using CONTAM (a validated multi-zone indoor air quality (IAQ) model) were employed to predict indoor exposure to PM2.5 in London dwellings in both the present day housing stock and the same stock following energy efficient refurbishments to meet greenhouse gas emissions reduction targets for 2050. To achieve these targets, measures were specified that reduced building permeability to $3 \mathrm{~m}^{3} \mathrm{~m}^{-2} \mathrm{hr}{ }^{-1}$ at $50 \mathrm{~Pa}$, combined with the introduction of mechanical ventilation and heat recovery (MVHR) systems. It was assumed that the mean current outdoor PM2.5 concentration of $13 \mu \mathrm{g} \cdot \mathrm{m}^{-3}$, decreased to $9 \mu \mathrm{g} \cdot \mathrm{m}^{-3}$ by 2050 due to emission control policies. Proper installation of MVHR systems with permeability reduction is associated with appreciable reductions in PM2.5 exposure in both smoking and non-smoking dwellings. Modelling of the future scenario for nonsmoking dwellings predicts a reduction in annual average indoor exposure to PM2.5 of $24.0 \mu \mathrm{g} \cdot \mathrm{m}^{-3}$ (from 28.4 to $4.4 \mu \mathrm{g} . \mathrm{m} 3$ ) for a typical household member and a larger reduction of $52.8 \mu \mathrm{g} \cdot \mathrm{m}^{-3}$ (from 60.5 to $7.7 \mu \mathrm{g} . \mathrm{m} 3$ ) for members exposed primarily to cooking-related particle emissions in the kitchen. Reductions in envelope permeability, without mechanical ventilation, produced a small increase $\left(+5.4 \mu \mathrm{g} \cdot \mathrm{m}^{-3}\right)$ in indoor $\mathrm{PM} 2.5$ concentrations. These estimates of changes in PM2.5 exposure were sensitive to assumptions about occupant behaviour, ventilation system usage and the distribution of input variables $(+72 \%$ for non-smoking and $+107 \%$ in smoking residences) but, if realised would result in significant health benefits.
\end{abstract}

Key words: PM2.5, Indoor, Domestic, Exposure, Modelling, Energy efficiency 


\section{Introduction}

Motivated in large part by the desire to pursue $\mathrm{CO} 2$ reduction targets for mitigating climate change, the energy efficiency of new and existing buildings in the UK are likely to be substantially improved over the coming decades (HM Government, 2010a). Existing dwellings are projected to account for approximately $80 \%$ of the housing stock in 2050 (Boardman, 2008). To meet 2050 greenhouse gas (GHG) reduction targets, current proposals suggest that these existing dwellings should undergo extensive retrofitting, with the installation of insulation and more efficient heating systems coupled with an increase in air tightness (Boardman, 2008, Wilkinson, et al., 2009). However, such changes to air tightness and ventilation are likely to lead to changes in indoor air quality and personal exposure to airborne pollutants such as particulate matter (PM) (Milner et al., 2005), the smaller fractions of which are harmful to health (COMEAP, 2009). As most people in developed countries typically spend $>80 \%$ of their time indoors (Klepeis et al., 2001); changes in domestic indoor air quality consequent to energy efficiency measures may impact population health (Wilkinson et al., 2009).

Concentrations of PM2.5 in houses are affected by the infiltration of outdoor particles, emissions from indoor sources and the removal from the internal air by deposition and filtration, though some re-suspension also occurs which is often related to domestic activities (Gehin et al., 2008). In apartments there is also the possibility of some interapartment transfer of contaminants via party wall permeability (Molnár et al., 2007).

Various external factors: building location, height, orientation to outdoor pollutant sources and prevailing meteorology affect outdoor PM2.5 contributions to indoor concentrations (Godish \& Spengler, 2004; Patra et al., 2008). Climate change effects on meteorology, vehicle traffic changes and the proposed introduction of energy efficient technologies to domestic properties will all affect population exposure to PM2.5 (Gerharz et al., 2009). In the future, external concentrations of PM25 are expected to decline due to reductions in transport emissions and gaseous precursors which produce secondary particles (Williams, 2007). Increased air tightness and installation of mechanical ventilation and heat recovery systems (MVHR) which filter out PM25, could lead to a reduction in externally generated PM2.5 in dwellings. However, any increase in airtightness without an increase in controlled purpose provided ventilation could lead to a rise in exposure from internally generated PM2.5 (Wilkinson et al., 2009).

Indoor PM2.5 concentration has been linked to transient internal sources such as construction materials, fixtures and fittings, and appliances as well as intermittent emissions such as the burning of fuels and candles, smoking, cooking, heating and human domestic activities (Milner et al., 2005; Weschler, 2009). Studies have shown high PM2.5 indoor concentrations relative to external levels, with cooking and smoking being the two primary sources (Jones et al., 2000). The behaviour of occupants and their movements, including window opening, can also affect indoor concentrations (Andersen et al., 2009). Within dwellings, different rooms could be subject to very different levels of PM2.5, depending on the activities conducted in them (Dimitroulopoulou et al., 2006). Methods are needed to assess the impact of cooking, smoking and domestic activities as well as ventilation behaviour in order to understand the impact of energy efficient refurbishment on future exposure.

This paper presents modelling evidence of indoor exposure to PM2.5 in current London dwellings, and an assessment of the likely impact of energy efficiency measures designed to meet 2050 climate change mitigation objectives. 


\section{Materials and Methods}

Modelling of exposure to PM2.5

The study was based on the application of CONTAM (Emmerich, 2001), a validated multizone indoor air quality (IAQ) model, to predict concentrations of particles with maximum aerodynamic diameter of 2.5 microns (PM2.5) in specific zones/rooms of dwellings dispersed by airflows from both indoor and outdoor sources. This modelling develops previously published methods of exposure characterization to PM2.5 (Wilkinson et al., 2009). It includes a detailed approach to modelling the ventilation systems within dwellings, occupant schedules, removal of PM2.5 via a deposition rate model and integrates complex empirical data sources as model inputs. A schema of the modelling approach is shown in Figure 1.

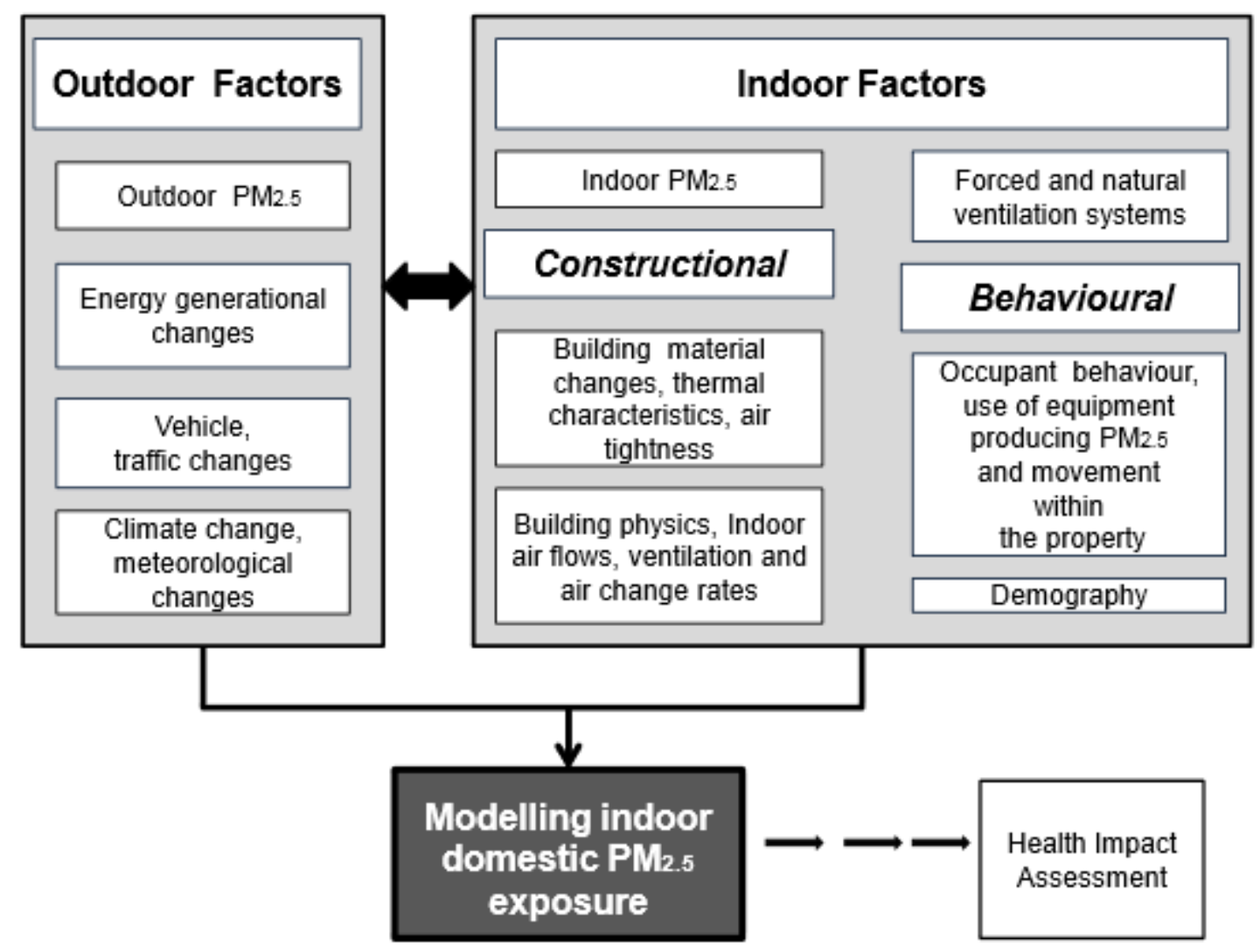

Figure 1 Range of factors affecting indoor PM2.5 exposure and preparation of data for future input to heath impact assessment.

The house and apartment models used were based on dwelling characteristics selected to be broadly representative of the London housing stock. Simulations were run to reflect combinations of key parameters: dwelling type, basic form (geometry), ventilation system and permeability levels (Table 1). All model scenarios were run including and omitting tobacco smoking, and particles from indoor sources, so as to quantify the separate contributions of smoking and particles of indoor and outdoor origin to the overall indoor PM2.5 concentrations. 
Table 1 Summary of key dwelling features, PM2.5 sources and external environment characteristics used for the specification of baseline simulations of the 2009 and 2050 housing stock.

\begin{tabular}{|c|c|c|c|}
\hline \multirow{10}{*}{$\begin{array}{l}\text { Common to } \\
\text { all } \\
\text { simulations } \\
\text { of current } \\
(2010) \text { and } \\
\text { future }(2050) \\
\text { stock }\end{array}$} & Dwelling type & \multicolumn{2}{|c|}{ House or Apartment* } \\
\hline & $\begin{array}{l}\mathrm{PM}_{2.5} \text { sources } \\
\text { and schedules }\end{array}$ & \multicolumn{2}{|c|}{ Models run (1) with $\mathrm{PM}_{25}$ source and (2) no source scenario } \\
\hline & 1.Cooking & \multicolumn{2}{|c|}{$\begin{array}{l}15 \text { mins morning and } 30 \text { mins evening cooking, with an additional lunch } \\
\text { period of } 30 \text { minutes at weekends (gives } 1.6 \mathrm{mg} \cdot \mathrm{min}^{-1} \text { emissions of } \mathrm{PM}_{2.5} \text { ) }\end{array}$} \\
\hline & 2.Smoking & \multicolumn{2}{|c|}{$\begin{array}{c}2 \text { cigarettes in the kitchen on weekdays and weekends and } 4 \text { cigarettes on } \\
\text { weekdays and } 7 \text { at weekends in the living room (giving } 0.99 \mathrm{mg} \cdot \mathrm{min}^{-1} \\
\text { emissions of } \mathrm{PM}_{2.5} \text { at } 5 \text { minutes per cigarette) }\end{array}$} \\
\hline & 3.Sweeping & \multicolumn{2}{|c|}{$\begin{array}{l}\text { Entrance/bathrooms and en-suites on Wednesday and Saturday only } \\
5 \text { minutes per room(giving } 0.05 \mathrm{mg} \cdot \mathrm{min}^{-1} \text { emissions } / \mathrm{re} \text {-suspension of } \mathrm{PM}_{2.5}\end{array}$} \\
\hline & 4.Vacuuming & \multicolumn{2}{|c|}{$\begin{array}{l}\text { All other rooms on Wednesday and Saturdays only, } 5 \text { minutes per room in } \\
\text { rotation (giving } 0.07 \mathrm{mg} \cdot \min ^{-1} \text { emissions } / \text { re-suspension of } \mathrm{PM}_{2.5} \text { ) }\end{array}$} \\
\hline & 5.Dusting & \multicolumn{2}{|c|}{$\begin{array}{l}\text { All rooms Saturdays only, } 20 \text { minutes per room in rotation (giving } 0.09 \\
\text { mg.min }{ }^{-1} \text { emissions/re-suspension of } \mathrm{PM}_{2.5}\end{array}$} \\
\hline & $\begin{array}{l}\text { 6.Washing } \\
\text { Machine }\end{array}$ & \multicolumn{2}{|c|}{$\begin{array}{l}\text { In Kitchen, scheduled for } 30 \text { minutes, } 3 \text { times a week } \\
\text { (giving } 0.12 \mathrm{mg} \cdot \mathrm{min}^{-1} \text { emissions of } \mathrm{PM}_{2.5} \text { ) }\end{array}$} \\
\hline & $\begin{array}{l}\text { 7. Washing/ } \\
\text { Showering }\end{array}$ & \multicolumn{2}{|c|}{$\begin{array}{l}\text { Bathroom and En-suite, daily morning and evening schedule for } 30 \\
\text { minutes(giving } 0.04 \mathrm{mg} \cdot \mathrm{min}^{-1} \text { emissions of } \mathrm{PM}_{25} \text { ) }\end{array}$} \\
\hline & Weather & \multicolumn{2}{|c|}{$\begin{array}{c}\text { CIBSE/Met Office hourly weather data - Test Reference Year and Design } \\
\text { Summer Year }\end{array}$} \\
\hline & & Current (2010) housing stock & $\begin{array}{l}\text { Stock under future (2050) } \\
\text { scenarios }\end{array}$ \\
\hline \multirow{3}{*}{$\begin{array}{l}\text { Specific to } \\
\text { simulations } \\
\text { of } 2010 \text { or } \\
2050 \\
\text { scenario }\end{array}$} & $\begin{array}{l}\text { Ventilation } \\
\text { regimes }\end{array}$ & $\begin{array}{l}\text { (1) infiltration and purge ventilation only: } \\
\text { (2) infiltration, trickle ventilators, } \\
\text { extraction fans and periodic purge } \\
\text { ventilation; }\end{array}$ & $\begin{array}{l}\text { ventilated via MVHR systems } \\
\text { with background /boost } \\
\text { modes and filters that remove } \\
80 \% \text { of } \mathrm{PM}_{2.5}\end{array}$ \\
\hline & Permeability & $\begin{array}{l}3,5,7,10,15,20,25,30 \\
\mathrm{~m}^{3} \mathrm{~m}^{-2} \mathrm{hr}^{-1} \text { at } 50 \mathrm{~Pa}\end{array}$ & $\begin{array}{l}3 \mathrm{~m}^{-3} \mathrm{~m}^{-2} \mathrm{hr}^{-1} \text { at } 50 \mathrm{~Pa}+\mathrm{MVHR} \\
\text { systems with filters removing } \\
\qquad 80 \% \text { of } \mathrm{PM}_{2.5}\end{array}$ \\
\hline & Outdoor $\mathrm{PM}_{2.5}$ & $13 \mu \mathrm{g} \cdot \mathrm{m}^{-3}$ & $9 \mu \mathrm{g} \cdot \mathrm{m}^{-3}$ \\
\hline
\end{tabular}

*The apartment (Figure 2) was modelled to be on the ground floor, with no adjustments for wind speed or change in PM2.5 concentrations with height. Emission inventories are based on data from Ozkaynak et al., 1996; He et al., 2004 and Afshari et al., 2005. 


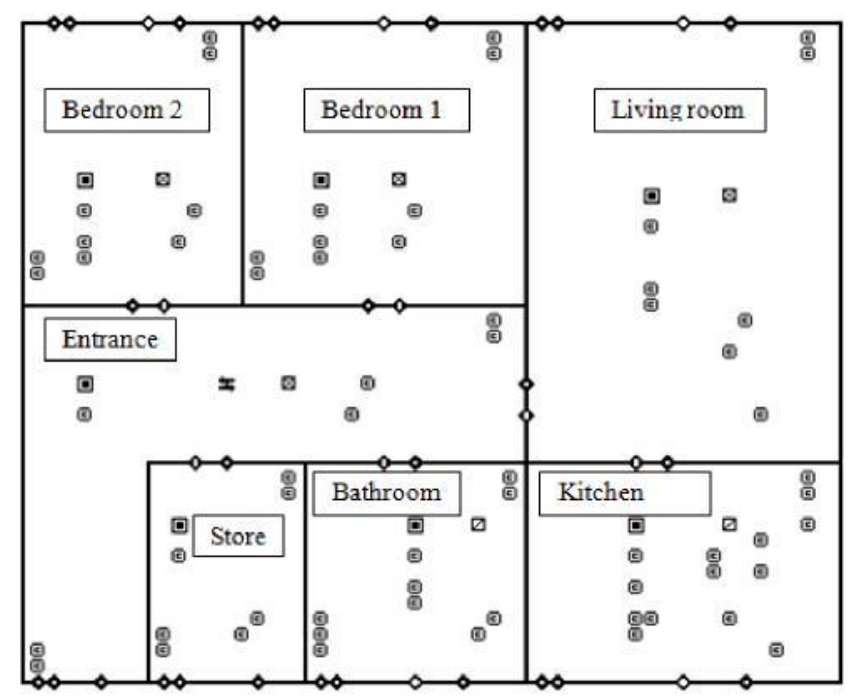

Figure 2 Schematic of simulated apartment in CONTAM with modelled rooms, pollutant sources/sinks, ventilation systems, windows, doors and adventitious infiltrations. The house was modelled over four levels.

Data inputs and assumptions

A number of assumptions were made for the input parameters to the CONTAM models. The emission rate of PM2.5 from cooking was assumed to be $1.6 \mathrm{mg} \cdot \mathrm{min}^{-1}+0.6 \mathrm{mg} \cdot \mathrm{min}^{-1}$ based on $4.1 \mathrm{mg} \cdot \mathrm{min}^{-1}+1.6 \mathrm{mg} \cdot \mathrm{min}^{-1}$ of inhalable PM10 of which $40 \%$ is the finer fraction of PM2.5, having a PM2.5 deposition rate of $0.39 \mathrm{hr}^{-1}$ (figures derived from the large scale PTEAM study (Ozkaynak et al., 1996)). However, it is acknowledged that emission rates vary greatly in the literature, depending on food type, cooking method, duration, appliance and method of measurement (He et al., 2004; Olson and Burke, 2006). As such, sensitivity analysis has been carried out to +2.33 standard deviations to capture $99 \%$ of the values for all emission sources.

All model simulations assume that the dwelling permeability is provided by adventitious openings (gaps and cracks) in the external walls, floors and roofs, with gap size proportional to facade area and assuming a crack is situated at the base and top of each wall. A penetration factor of 1 was used for all infiltration pathways in the models, as representing the maximum for PM2.5, although component size, indoor/outdoor pressure differences and the geometry and roughness of individual building penetrations may affect this value. Consequently, sensitivity analysis contrasts this value with 0.6 from Chen and Zhao (2011).

Based on the absence of suitable data, fixed periods and durations of all domestic activities were assumed (Table 1) In smoking dwellings, based on Office of National Statistics data (ONS, 2000), it was assumed 1 cigarette was smoked per waking hour; the schedule assumes some smoking occurs both outdoors and indoors in the kitchen and living room. Extractor fans, trickle-ventilators and MVHR systems were specified to comply with Approved Document $F$ of the Building Regulations for England (HM Government, 2010b). Equipment was modelled to be correctly fitted and perfectly functioning with filter efficiency of $80 \%$ for PM2.5 particles.

For the present day stock we assumed two ventilation strategies: (1) ventilation achieved via adventitious openings, trickle ventilators, intermittent extract fans and periodic purge ventilation by window opening (representing $20 \%$ of stock, which has been refurbis hed, or constructed in line with current regulations) or (2) ventilation achieved via adventitious openings and periodic purge ventilation by window opening but without trickle ventilators or 
extraction fans ( $80 \%$ of stock). The proportions of the stock are informed by the number of dwellings built post 1995 when amendments to Part F of the Building Regulations (1995) were introduced requiring trickle ventilation and extract fans, and data from the Warm Front study, which estimates the percentage of pre-1995 properties already fitted with intermittent extract fans (ONS, 2011a; Warm Front, 2011).

Outdoor conditions including temperature are perceived as the most important factor influencing window opening behaviour, with the proportion of windows open, time and aperture lowest in winter, medium in spring and autumn, and highest in summer (Rijal et al., 2007, Andersen et al., 2009). Accordingly, we assumed a seasonal variation with a base case where windows were opened to $10 \%$ of the maximum aperture for 8 hours during the summer months and closed during the winter months (except during purge events for cooking, bathroom and toilet usage) and then subjected these schedules to sensitivity analysis. Eight levels of permeability were used for exterior façades: $3,5,7,10,15,20,25$ and $30 \mathrm{~m}^{3} \mathrm{~m}^{-2} \mathrm{hr}^{-1}$ at $50 \mathrm{~Pa}$. These values reflect the observed distribution of the UK domestic stock and in the absence of other data, are assumed to be broadly representative of London (Stephen, 1998).

Internal walls (including party walls) are considered impermeable and any inter-apartment PM2.5 transfer assumed to be relatively small and generally countervailing. Doors when shut, have a small element of permeability representing the gap between door and frame. For 'new' dwellings, a gap to allow for the functioning of the MVHR system has been modelled in line with Approved Document F (2010). Internal doors (excluding storage) are generally open to allow free air-flow except during activities such as cooking and bathroom use.

For the outdoor PM25, the calculated mean annual average concentration measured at urban background monitoring stations in the Automatic Urban and Rural Network (AURN) for London and the London Air Quality Network (LAQN, 2010) was used. Annual mean PM2.5 concentration across 20 urban background stations was $13 \mu \mathrm{g} \cdot \mathrm{m}^{-3}$ with a variance of $2.9 \mu \mathrm{g} . \mathrm{m}$ 3. Simulated weather conditions were based on CIBSE/Met Office hourly data - Test Reference Year (TRY) and Design Summer Year (DSY) - enabling winter and summer model versions to be constructed, which were assumed to representative of current day (2010) conditions. Indoor temperature profiles with room averages: winter $\left(18.75-20.35^{\circ} \mathrm{C}\right)$ and summer $\left(23.65-24.35^{\circ} \mathrm{C}\right)$ were informed by a study from FMNectar (2007), which investigated ventilation effectiveness in support of Part $F$ of the Building Regulations.

For the 2050 housing stock, it was assumed that all dwellings are refurbished to a permeability of $3 \mathrm{~m}^{3} \mathrm{~m}^{-2} \mathrm{hr}^{-1}$ at $50 \mathrm{~Pa}$ and are ventilated by MVHR systems with filters that remove $80 \%$ of $\mathrm{PM} 2.5$. The choice of this scenario was motivated to meet UK targets which aim to reduce CO2 emission by $80 \%$ by the year 2050 (CCC, 2011). The assumption of complete refurbishment to this standard and installation of MVHR to all of the London stock is a deliberately extreme scenario to illustrate the maximum feasible impact on the indoor environment. For outdoor PM2.5 a concentration of $9 \mu \mathrm{g} \cdot \mathrm{m}^{-3}$ was assumed (Williams, 2007). In order to investigate the effects of changing climate on the future (2050) scenario, weather files were created by adjusting current day files in line with climate models based on particular emission scenarios from UK Energy Research Centre (UKERC, 2009) using the method proposed by Belcher et al. (2005). However, as these showed no significant impact $(<0.1 \%)$ on annual indoor PM2.5 concentrations, weather files representing 2010 were used throughout this study.

Personal exposure and occupancy schedules

Personal exposure to PM2.5 was estimated from the simulations for three categories of occupancy schedule. Firstly, (a) a base case or 'household average' from Wilkinson et al, 
(2009) using an average annual concentration of PM2.5 in the living room, bedroom and kitchen using time weighting factors of $0.45,0.45$, and 0.1 respectively. This was modified to produce (b) the exposure experienced by a 'cook' who occupies the living room, bedroom and kitchen during periods of cooking using weighting factors of $0.56,0.36$ and 0.08 on weekdays and $0.4,0.5$ and 0.1 at weekends respectively; and (c) the exposure of a person who never enters the kitchen and only spends time in the living room and bedroom with weighting 0.62 and 0.38 on weekdays and 0.58 and 0.41 at weekends respectively.

London stock mean PM25 exposures were calculated by post-processing the results from the simulations using weightings that reflect the frequency (proportion) of the permeability distribution within the UK domestic stock (Stephen, 1998) and that $50 \%$ of current London dwellings are apartments, and $50 \%$ houses (based on Office for National Statistics data) (ONS, 2011).

Sensitivity analysis of estimates of PM2.5 exposure

Differential sensitivity analysis (DSA) was carried out to examine the sensitivity of the results to model inputs and assumptions. This method assumes that the effect of each variable is independent and additive. For numerical parameters (e.g. PM2.5 emission and deposition rates) high and low values were calculated as the means +2.33 standard deviations - the range that encompasses $99 \%$ of the values assuming normally distributed data (Lomas and Eppel, 1992). For other variables such as window opening, where field data is sparse, we proposed specific ranges thought likely to reflect the scope of normal behaviour, by changing the open period by +2 hours and increasing the open area to $40 \%$. For building orientation, the dwellings were rotated in steps of 45 degrees.

Additional investigation of the effects of location on external PM2.5 concentrations within the Greater London authority (GLA) were carried out using OSPM (Vardoulakis et al., 2007). Residences in London were subdivided into houses and apartments and further classified in three broad exposure categories - high, moderate and low - based on distance from busy streets and/or intersections as explained by Vardoulakis et al. (2008). OSPM was run using composite meteorological and urban background PM2.5 files of $13 \mu \mathrm{g} \cdot \mathrm{m}^{-3}$ for the present day and $9 \mu \mathrm{g} \cdot \mathrm{m}^{-3}$ for 2050 . Vehicle traffic and emission data for A (Major road, non-motorway) and minor roads for the same years were constructed with eight typical London street configurations.

Model runs using different weather files (Heathrow TRY, Heathrow DSY and Gatwick International Weather for Energy Calculation (IWEC) were performed to consider possible effects of meteorological variation (CIBSE, 2010). Analysis examined the effect of altering the height of the infiltration gaps by $+0.1 \mathrm{~m}$ from the initial height of $2.3 \mathrm{~m}$. Uncertainty in room volumes are informed by Chapman (1994) based on the range of storey heights (2.3$2.6 \mathrm{~m}$ ) within the GLA. These yield average room volume changes of $+8.6 \%$ from the baseline models. Sensitivity to length of window opening was tested by examining the effect of opening windows +1 hour in the morning and closing them +1 hour in the evening in summer and increasing the opening area to 40 percent. Indoor zone temperatures were varied by adjusting the room schedules by $+2^{\circ} \mathrm{C}$.

The maximum and minimum alternative values of each input parameter were tested individually, while holding all other variables constant. The results are reported as the percentage difference in PM2.5 concentrations compared with the central baseline estimate In the case of building orientation the mean deviation from the base line value (north) was calculated. 


\section{Results}

The results of the CONTAM simulations of PM2.5 exposure are presented in Tables 3a-b. Comparisons with empirical and modelled data are included within the discussion section.

Non-smoking households

Table 3a Non-smoking residences: simulated average annual London indoor domestic PM2.5 exposures for the present day and 2050

Annual average PNR5 $\left(\mu \mathrm{g} \cdot \mathrm{m}^{-3}\right)$

\begin{tabular}{|c|c|c|c|c|c|}
\hline Year & $\begin{array}{l}\text { Exposure } \\
\text { Model }\end{array}$ & $\begin{array}{ll}\text { Indoor exposure tolndoor } \\
\text { PM2.5 from indoorPM2.5 } \\
\text { sources (row percent) air (rou }\end{array}$ & $\begin{array}{l}\text { exposure to } \\
\text { from outdoor } \\
v \text { percent) }\end{array}$ & Total & $\begin{array}{l}\text { Change } \\
\text { total indoor } \\
\text { PM2.5 } \\
2010-2050\end{array}$ \\
\hline \multirow{3}{*}{$\begin{array}{l}\text { Present } \\
\text { (External } \\
\text { PM2.5 } \\
13.0 \mu \mathrm{g} \cdot \mathrm{m}^{-3} \text { ) }\end{array}$} & $\begin{array}{c}\text { DayHousehold } \\
\text { Average }\end{array}$ & $22.0(77 \%)$ & $6.4(23 \%)$ & 28.4 & \\
\hline & Cook & $54.2(90 \%)$ & 6.3 (10\%) & 60.5 & \\
\hline & Non-cook & $9.4(61 \%)$ & 6.1 (39\%) & 15.5 & \\
\hline \multirow{3}{*}{$\begin{array}{l}2050 \\
\text { (External } \\
\text { PM2.5 } \\
9.0 \mu \mathrm{g} \cdot \mathrm{m}^{-3} \text { ) }\end{array}$} & $\begin{array}{l}\text { Household } \\
\text { Average }\end{array}$ & $3.5(80 \%)$ & $0.9(20 \%)$ & 4.4 & $-85 \%$ \\
\hline & Cook & $6.9(90 \%)$ & $0.8(10 \%)$ & 7.7 & $-87 \%$ \\
\hline & Non-cook & $1.0(56 \%)$ & $0.8(43 \%)$ & 1.8 & $-88 \%$ \\
\hline
\end{tabular}

The results suggest that under present day conditions, average indoor concentrations of PM2.5 are appreciably higher than those in the outdoor air because of indoor sources. Thus in nonsmoking dwellings, although indoor levels of PM2.5 derived from outdoor air are less than half the outdoor levels, the concentration experienced by the average household member indoors was estimated to be $28.4 \mu \mathrm{g} \cdot \mathrm{m}^{-3}$, over twice the concentration in the outdoor air (13.0ug.m $\left.{ }^{-3}\right)$.

Under the 2050 refurbishment scenario, household average exposure to total PM2.5 (from indoor and outdoor sources) is reduced from $28.4 \mu \mathrm{g} \cdot \mathrm{m}^{-3}$ to $4.4 \mu \mathrm{g} \cdot \mathrm{m}^{-3}$ (-85\%). The contribution from external sources represents $23 \%$ of the current total indoor PM2.5 exposure and $20 \%$ in 2050. Average London domestic stock Indoor/outdoor (V/O) ratios for PM2.5 from external sources are 0.5 for present day and 0.1 for 2050 due to the decrease in stock permeability and filters on the MVHR system and range hoods.

A separate 2050 scenario (results not presented in full here) with the proposed reduction in permeability to $3 \mathrm{~m}^{3} \mathrm{~m}^{-2} \mathrm{hr}^{-1}$ at $50 \mathrm{~Pa}$ without providing an MVHR system, resulted in an increase in the London annual average indoor exposure to total PM25 of $5.4 \mu \mathrm{g} \cdot \mathrm{m}^{-3}$ from the baseline of $28.4 \mu \mathrm{g} \cdot \mathrm{m}^{-3}$. This relatively small increase is due to the countervailing influences of decreases in outdoor PM2.5 penetration and increases in the indoor PM2.5 component. Application of correctly installed and perfectly functioning MVHR equipment results in a reduction in exposure of $24.0 \mu \mathrm{g} \cdot \mathrm{m}^{-3}$ from the baseline scenario of $28.4 \mu \mathrm{g} \cdot \mathrm{m}^{-3}$. The simulations suggest that occupants without extraction fans in the kitchen are exposed to a household average exposure up to four times greater than occupants in a similar apartment with functioning fans with a minimum intermittent extract rate of $60 \mathrm{l} / \mathrm{s}$.

There was considerable variation in PM2.5 exposure levels among household members. The simulations show that in non-smoking households peak exposure levels are related to 
periods of cooking in the kitchen. In consequence, the results for cooks suggest that they experience twice the level of PM2.5 exposure of the average household member, and more than four times that of a 'non cook' who does not enter the kitchen. This is because the average cook is exposed to 5.8 times the internally generated PM2.5 compared with the average non cook, while both are exposed to roughly similar levels of externally generated PM2.5. The household average PM2.5 exposure (the time-weighted average of PM2.5 experienced in the living room, bedroom and kitchen) approximates the average exposure of a family of one cook and three non-cook members (average exposure $=26.8 \mu \mathrm{g} \cdot \mathrm{m}^{-3}$ ).

Smoking households

Table 3b Smoking residences: simulated average annual London indoor domestic PM2.5 exposures for the present day and 2050

Annual average PN25 $\left(\mu \mathrm{g} \cdot \mathrm{m}^{-3}\right)$

\begin{tabular}{lllll}
\hline Year & Exposure & Indoor exposure tolndoor exposure to & Change in \\
& Model & PM2.5 from indoorPM2.5 from outdoor Total & total indoor \\
& sources (row percent) air (row percent) & PM2.5 \\
& & & $2010-2050$ \\
\hline
\end{tabular}

\begin{tabular}{|c|c|c|c|c|c|}
\hline \multirow{3}{*}{$\begin{array}{l}\text { Present } \\
\text { (External } \\
\text { PM2.5 } \\
13.0 \mu \mathrm{g} \cdot \mathrm{m}^{-3} \text { ) }\end{array}$} & $\begin{array}{c}\text { DayHous ehold } \\
\text { Average }\end{array}$ & $51.4(89 \%)$ & $6.4(11 \%)$ & 57.8 & 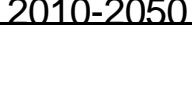 \\
\hline & Cook & $96.0(94 \%)$ & $6.3(6 \%)$ & 102.3 & \\
\hline & Non-cook & $51.0(95 \%)$ & $6.1(5 \%)$ & 57.1 & \\
\hline \multirow{3}{*}{$\begin{array}{l}2050 \\
\text { (External } \\
\text { PM2.5 } \\
9.0 \mu \mathrm{g} \cdot \mathrm{m}^{-3} \text { ) }\end{array}$} & $\begin{array}{l}\text { Household } \\
\text { Average }\end{array}$ & $22.0(96 \%)$ & $0.9(4 \%)$ & 22.9 & $-60 \%$ \\
\hline & Cook & $42.3(98 \%)$ & $0.8(2 \%)$ & 43.1 & $-58 \%$ \\
\hline & Non-cook & $31.7(98 \%)$ & $0.8(2 \%)$ & 32.5 & $-43 \%$ \\
\hline
\end{tabular}

According to the English Housing Survey 2009, the proportion of properties in London with smokers is $18.9 \%$ (EHS, 2009). For smoking households, the concentration experienced by the average household member is $57.8 \mu \mathrm{g} \cdot \mathrm{m}^{-3}$; over four times the outdoor concentration. The external PM2.5 component now represents a substantially smaller proportion (11\%) of the overall exposure. The non-cook receives a similar exposure $\left(57.1 \mu \mathrm{g} \cdot \mathrm{m}^{-3}\right)$ due to PM2.5 emissions from smoking occurring in the living room. The cook experiences an annual average increase in PM2.5 exposure of + $41.8 \mu \mathrm{g} . \mathrm{m}^{-3}$ compared to the non-smoking scenario $\left(60.5\right.$ to $\left.102.3 \mu \mathrm{g} . \mathrm{m}^{-3}\right)$. The 2050 refurbishments reduce the indoor exposure substantially. However, with reduced permeability and the MVHR system designed according to Approved Document F (HM Government, 2010b) occupants still experience exposures between 2.5 and 4.8 times the external PM2.5 concentration of $9.0 \mu \mathrm{g} \cdot \mathrm{m}^{-3}$.

These results for both smoking and non-smoking households represent only time spent in the indoor domestic environment. In order to quantify overall personal exposure to PM2.5 and consequent health impacts, time spent in other microenvironments (e.g. in transport, at work) and outdoors will need to be taken into account (Wallace et al., 2006).

Sensitivity Analysis

The results of the sensitivity analysis are shown in Table 4. The percentage change in PM2.5 concentration for each variable represents its independent effect on the baseline model results when the specified 'high' or 'low' values of the relevant parameter are used. (For 
numerical variables these are +2.33 standard deviations. The quadrate sum is calculated from the square of these values, enabling the overall error in the baseline values to be obtained.

Table 4 Input variables altered to perform analysis and the resultant percentage changes in average annual indoor personal PM2.5 exposure for present day London stock based on the $45 \%, 45 \%, 10 \%$ occupation scenario

\begin{tabular}{ll} 
Variable & $\begin{array}{l}\text { Average \% difference } \\
\text { in PM2.5 estimate }\end{array}$ \\
& \\
\hline Building Orientation & +3.7 \\
Infiltration Height & +0.2 \\
Volume & +4.2 \\
Indoor Temperature & +0.6 \\
Window Opening & +18.3 \\
PM2.5 Infiltration Rate & +9.0 \\
PM2.5 Emission Rate & +36.2 \\
PM2.5 Deposition Rate & +59.1 \\
Weather File Changes & +1.3 \\
Quadrate Sum & $+72.4^{*}$ \\
\hline
\end{tabular}

* In smoking houses this rises to $+106.7 \%$ from the base line rate based on the increase in PM2.5 emissions

Indoor PM2.5 deposition and emission rate and window opening behaviour have the largest influence on the overall PM2.5 concentrations; with generally smaller impacts from building orientation, infiltration height, volume, indoor temperature and external weather conditions. Results from OSPM confirmed location as a less critical variable as they showed a maximum PM2.5 external variation of $2.22 \mu \mathrm{g} \cdot \mathrm{m}^{-3}$ against an urban background value of $13.0 \mu \mathrm{g} . \mathrm{m}^{-}$ ${ }^{3}$,with a variation of $1.38 \mu \mathrm{g} \cdot \mathrm{m}^{-3}$ against a 2050 urban background value of $9.0 \mu \mathrm{g} \cdot \mathrm{m}^{-3}$ in the 2050 scenario . The quadrate sum for smoking $(+106.7 \%)$ and non-smoking properties ++ $72.4 \%$ ) show very large variations in pM2.5 exposure are possible.

It should be stressed that there is variation in the uncertainty of the individual parameters used. For example, variability in building height and volume (Chapman, 1994) is better understood than variability in behaviour and window opening (Andersen et al., 2009).

\section{Discussion}

General findings

This study provides new insights into the potential effect of changes to the energy efficiency of London's housing stock on exposure to PM25. Overall, these findings provide comparative evidence of the possible effects on personal indoor PM2.5 exposure brought about by the application of $\mathrm{CO} 2$ mitigation strategies as well as the potential for the reduction of other airborne pollutants by the use of extraction and filtration. The results show that domestic energy efficiency interventions motivated by climate change objectives could yield substantial reductions in PM2.5 exposure. However, the magnitude and directions of exposure changes are dependent on the details of the specific mitigation package. Adverse effects may occur, for example, if airtightness is achieved without the associated installation and maintenance of correctly functioning ventilation systems.

The sensitivity analysis indicates that there are large uncertainties in PM2.5 emissions and deposition rates which influence exposure. The other major factors affecting personal indoor exposure appear to be non-locational and relate to changes to the building envelope, ventilation systems and occupant activity implying that behaviour can potentially have a large 
effect on PM2.5 exposure. This has implications for policy, for example the installation and use of high efficiency extractor fans/range hoods to avoid high PM2.5 exposures during cooking seems a relatively low cost intervention, potentially yielding substantial heath benefits.

Reductions in permeability and the application of MVHR systems could result in the effective control of indoor sources in non-smoking households, however they also lead to markedly lower exposures from outdoor sources. For this exposure, therefore, the simulated changes are likely to be positive for health, and that may add to the case for pursuing energy efficiency interventions - if properly implemented. The presented results shown should be interpreted with caution as they are dependent on the range of assumptions and input parameters specified. In particular, field studies show high variability in PM2.5 emission rates from cooking: $2.4+2.1 \mathrm{mg}_{\mathrm{min}}{ }^{-1}$ (He et al., 2004), 36+98mg.min ${ }^{-1}$ (Olson and Burke, 2006), 1.6+0.6 mg. $\mathrm{min}^{-1}$ (Ozkaynak et al., 2006). Similarly, there are variations in deposition rate calculation methodologies with differing interpretations of surface area (Fogh et al., 1997; Thornburg, et al., 2001), which could lead to differences in absolute PM2.5 exposures.

Direct comparisons with results from other studies are therefore difficult because of differences in housing stock profiles, populations, time frames, mean calculations and other factors. The specification of the 2050 stock was deliberately based on an extreme scenario, with all dwellings reduced in permeability to $3.0 \mathrm{~m}^{3} \mathrm{~m}^{-2} \mathrm{hr}^{-1}$ and fitted with MVHR systems, combined with effective $80 \%$ particle filtration. However, the current 'Retrofit for the Future' program contains examples of construction refurbishment projects in London employing MVHR systems and achieving substantial reductions in permeability down in some cases to the Passivhaus standard of $0.6 \mathrm{~m}^{3} \mathrm{~m}^{-2} \mathrm{hr}^{-1}$ (LEB, 2011). So, whilst such permeabilities are achievable, the impacts seen on PM2.5 levels are therefore likely to be towards the maximum of what could be achieved. They do however, suggest possible positive effects on PM2.5 exposures from energy efficiency measures implemented as part of a strategy for meeting abatement targets as specified by the UK Climate Change Committee (CCC, 2011). To make clear the effect of these housing changes, the models assumed no changes in behaviour or new technologies, which could influence indoor air quality, save for the assumption of a lower outdoor PM2.5 concentration in 2050.

Comparison with empirical studies

The results of this study are broadly consistent with on-site measurements of average annual indoor domestic PM2.5 concentrations. Our estimated non-smoking household average exposure for London of $28.6 \mu \mathrm{g} \cdot \mathrm{m}^{-3}$ is higher than that recorded as part of the EXPOLIS study in Oxford, UK, Lai et al. (2004), where the mean residential indoor PM25 concentration was $17.3 \mu \mathrm{g} \cdot \mathrm{m}^{-3}$. However, Hanninen et al. (2004) as part of the EXPOLIS project monitored indoor PM2.5 concentrations in non-smoking households in four European cities, (some of which may represent a more appropriate comparison to London), showing the following variations: Athens $23+11 \mu \mathrm{g} \cdot \mathrm{m}^{-3}$; Basle $17+8 \mu \mathrm{g} \cdot \mathrm{m}^{-3}$; Prague $25+16 \mu \mathrm{g} \cdot \mathrm{m}^{-3}$ and Helsinki 25+16 $\mathrm{gg}_{\mathrm{m}} \mathrm{m}^{-3}$. Wallace et al. (2006) monitoring 36 residences in North Carolina over a year showed mean indoor PM2.5 concentrations of $25.8 \mu \mathrm{g} \cdot \mathrm{m}^{-3}$ with a range of $7.2-66.0 \mu \mathrm{g} . \mathrm{m}^{-3}$ for non-smoking households. Substantial variations are seen in empirical studies on smoking concentrations including PM2.5. For smoking properties a consumption of 7.4 cigarettes per day resulted in an average indoor PM2.5 concentration of $132.7 \mu \mathrm{g} \cdot \mathrm{m}^{-3}$ measured over 14 days while 4 cigarettes over 19 days yielded $66.0 \mu \mathrm{g} \cdot \mathrm{m}^{-3}$. The present study showed a PM2.5 concentration of $57.8 \mu \mathrm{g} \cdot \mathrm{m}^{-3}$ for 11 cigarettes per day modelled over a year.

Dimitroulopoulou et al., 2005 in a monitoring study on kitchens in 37 new homes in the UK 
with smokers found 24 hour mean PM25 concentrations of $113 \mu \mathrm{g} \cdot \mathrm{m}^{-3}$ in winter and $134 \mu \mathrm{g} \cdot \mathrm{m} 3$ in summer.

Comparison with other modelling studies

The results of this modelling study are generally consistent with those of other published research. Dimitroulopoulou et al. (2006), using the INDAIR probabilistic model calculated annual indoor mean PM2.5 concentrations of $19.78 \mu \mathrm{g} \cdot \mathrm{m}^{-3}$ (calculated to correspond to the base case (a) occupancy scenario) in households with gas cooking, with a peak value of $318 \mu \mathrm{g} \cdot \mathrm{m}^{-3}$ (compared with $442 \mu \mathrm{g} \cdot \mathrm{m}^{-3}$ for this present study) and a standard deviation of $78 \mu \mathrm{g} \cdot \mathrm{m}^{-3}$ in the kitchen. Fabian et al. (2011), using CONTAM to model low-income multifamily housing with a higher cooking emission rate of $1.56 \mathrm{mg} \cdot \mathrm{min}^{-1}$ calculated a mean indoor PM2.5 concentration of $52.9 \mu \mathrm{g} \cdot \mathrm{m}^{-3}$ with a standard deviation of $41.4 \mu \mathrm{g} \cdot \mathrm{m}^{-3}$. . A separate sequence of 1000 random households indicated a drop in PM2.5 concentration from 42.0 to $28.8 \mu \mathrm{g} \cdot \mathrm{m}^{-3}(-34 \%)$ which was achieved by fitting extract fans in all kitchens. Emmerich and Howard-Reed, (2005), using CONTAM modelling as part of the U.S Dept of Housing and Urban Development's Healthy Homes Initiative, found the two most effective intervention strategies for indoor air quality were extract fans, if operated during source events (kitchen fan airflow rate $47 \mathrm{Vs}$ ) and efficient air filtration on heating ventilation and air conditioning (HVAC) systems, if operated for a minimum 15\% of the time. Our result for the household average PM2.5, VO ratio for the 2050 scenario of 0.1 for an external concentration of $9 \mu \mathrm{g} \cdot \mathrm{m}^{-3}$ using an MVHR system at $80 \%$ filter efficiency are consistent with results from Mackintosh et al. (2010) with a PM2.5, //O ratio 0.1 for an external concentration of $15 \mu \mathrm{g}^{-3} \mathrm{~m}^{-3}$.

Future work with a larger set of geometries that are more representative of the London stock could consider a probabilistic approach such as Monte Carlo Analysis (MCA) which was deemed computationally prohibitive and beyond the scope of this study. Unlike DSA, MCA is unable to detect effects of component variables (Dutton, et al., 2008). However, in reality many of the individual input variables within the CONTAM models are linked, e.g. window opening and air change rates and as such they are not truly linear and superposable (an assumption of DSA techniques used). MCA could provide an indication of homes with overall characteristics likely to lead to higher indoor concentrations of PM2.5 (Dimitroulopoulou et al., 2006).

\section{Conclusions and future work}

This study has developed and applied a series of model simulations in CONTAM to quantify the changes in indoor domestic exposure to PM2.5 in the Greater London Area as a result of the application of energy efficiency measures to meet 2050 greenhouse gas abatement targets. It has quantified the key variables impacting on indoor PM2.5 exposure and shown that constructional and occupational factors are major influences, with building location having a relatively smaller effect. The methodology used in this paper could be used to assess a wide variety of refurbishment strategies, differing pollutants and changes to occupant behaviour. Although there are very large uncertainties associated with the results, the analysis suggests substantial reductions in PM2.5 exposure which are likely to be beneficial for health in most cases if the interventions are implemented appropriately. It also suggests that present day high exposures for cooks from particle emissions during cooking in domestic environments are avoidable through a comparatively simple adaptation such as the introduction of extraction equipment or by properly fitted maintained and operated MVHR systems. Removal of some indoor PM2.5 emissions from smoking occurs, which benefits non-smokers in dwellings. Further work is now needed to produce a wider range of geometries based on built-form data for the Greater London Area focusing on variations in PM2.5 exposure between building geometries, temperature regimes, occupant behaviour, particle penetration and seasonal/diurnal changes in external PM2.5 concentrations.

Acknowledgements 
This work was carried out as part of the project "Pollutants in the Urban Environment: An Integrated Framework for Improving Sustainability of the Indoor Environment (PUrE Intrawise)", funded by EPSRC (Grant no. EP/F007132/1). The authors gratefully acknowledge this funding.

\section{References}

Adgate, J.L., Mongin, S.J., Pratt, G.C., Zhang, J., Field, M.P., Ramachandran, G., Sexton, K., 2007. Relationships between personal, indoor and outdoor exposures to trace elements in PM2.5. Science of the Total Environment 386, 21-32.

Afshari, A., Matson, U., Ekberg, L.E., 2005. Characterization of indoor sources of fine and ultrafine particles: a study conducted in a full-scale chamber. Indoor Air 15:141e50.

Andersen, R.V., Toftum, J., Andersen, K.K., Olesen, B.W., 2009. Survey of occupant behaviour and control of indoor environment in Danish dwellings. Energy and Buildings 41, 11-16.

Belcher, S., Hacker, J., Powell, D., 2005. Constructing design weather data for future climates. Building Services Engineering Research and Technology 26, 49 -61.

Boardman, B., 2008. Home Truths: a low carbon strategy to reduce UK housing emissions by $80 \%$ by 2050 , Environmental Change Institute, University of Oxford, UK.

CCC, 2011. The Committee on Climate Change: Adapting to climate change in the UK: Measuring progress. Adaptation Sub-Committee Progress Report 2011, last accessed $28^{\text {th }}$ March 2012 at http://www.theccc.org.uk/reports/adaptation/2nd-progress-report-2011 Chapman, P. F., 1994. A geometrical model of dwellings for use in simple energy calculations. Energy and Buildings 21, 83-91.

Chen, C., Zhao, B., 2011. Review of relationship between indoor and outdoor particles: 1/O Ratio, infiltration factor and penetration factor. Atmospheric Environment 45, 275-288.

COMEAP., 2009. Long-Term Exposure to Air Pollution: Effect on Mortality. Committee on the Medical Effects of Air Pollutants, Health Protection Agency, Didcot, UK.

CIBSE, 2010. Chartered institution of Building Services Engineers. Last accessed 9th

September 2011 at http://www.cibse.org/

Dimitroulopoulou, C., Crump, D., Coward, S.K.D., Brown, B., Squire, R., Mann, H., White, M.., Pierce, B., Ross, D., 2005. Ventilation, Air Tightness and Indoor Air Quality in New Homes. BR477, BRE Bookshop.

Dimitroulopoulou, C., Ashmore, M.R., Hill, M.T.R., Byrne, M.A., Kinnersley R., 2006. INDAIR: a probabilistic model of indoor air pollution in UK homes. Atmospheric Environment 40, 6323-6379.

Dutton, S., Shao, L., Riffat, S., 2008. Validation and Parametric analysis of EnergyPlus: Airflow network model using CONTAM. Third National Conference of IBPSA- USA, Berkley, California, July $30^{\text {th }}-$ August $1^{\text {st }}$.

EHS, 2009. English Housing Survey, Last accessed $13^{\text {th }}$ April 2012 at http://www.communities.gov.uk/publications/corporate/statistics/ehs200910headlinereport

Emmerich, S.J., 2001. Validation of Multizone IAQ Modelling of Residential-Scale Buildings: A Review. National Institute of Standards and Technology, Gaithersburg, MD. ASHRAE Transactions, 107, Pt. 2, Cl-01-8-1; Last accessed 29th April 2011 at http://www.bfrl.nist.gov/IAQanalysis/docs/valfinal.pdf

Emmerich, S.J., Howard-Reed, C., Gupte, A., 2005. Modeling the IAQ impact of HHI interventions in inner-city housing. NISTIR 7212, Gaithersburg, MD: National Institute of Standards and Technology.

Fabian, P., Adamkiewicz, G., Levy, J.I., 2011 Simulating indoor concentrations of NO2 and PM2.5 in multi-family housing for use in health-based intervention modeling Indoor Air DOI: 10.1111/j.1600-0668.2011.00742.x

FMNectar, 2007. Private communication. Investigation of ventilation effectiveness in support of Part F of the Building Regulations' Final Report No Cl 71/6/44 (BD2523).

Fogh, C. L., Byrne, M. A., Roed, J., Goddard, J. H., 1997. Size specific indoor aerosol deposition measurements and derived $\mathrm{l} / \mathrm{O}$ concentrations ratios. Atmospheric Environment 31, 2193-2203. 
Fox, J., 2009. A study of occupant controlled ventilation in UK dwellings. Thesis (PhD) University College, London. UK.

Gerharz, L. E., Krüger, A., Klemm, O., 2009. Applying indoor and outdoor modelling techniques to estimate individual exposure to PM2.5 from personal GPS profiles and diaries: a pilot study. The science of the total environment 407, 18, 5184-93.

doi: 10.1016/j.scitotenv.2009.06.006.

Gehin, E., Ramalho, O., Kirhner, S., 2008. Size distribution and emission rate measurement of fine and ultrafine particle from indoor human activities. Atmospheric Environment 42, 8341-8352.

Godish, T., Spengler, J. D., 2004. Relationships between ventilation and indoor air quality: a review. Indoor Air 6, 2, 135-145.

Hanninen, O.O., Lebret, E., llacqua, V., Katsouyanni, K., Kunzli, N., Sram, R.J., Jantunen, M., 2004. Infiltration of ambient PM25 and levels of indoor generated non-ETS PM2.5 in residences of four European cities. Atmospheric Environment 38, 6411-6423.

He, C., Morawska, L., Hitchins, J., Gilbert, D., 2004. Contribution from indoor sources to particle number and mass concentrations in residential houses. Atmospheric Environment 38, 3405-3415.

HM Government, 2010a. Low Carbon Construction: Innovation and Growth Team: Final Report. Crown Copyright 2010. Last accessed 21 $21^{\text {st }}$ August 2011 at http://www.bis.gov.uk/assets/biscore/business-sectors/docs///10-1266-low-carbon-

construction-igt-final-report.pdf.

HM Government, 2010b. The Building Regulations 2000 (2010 edition): Approved Document F1: means of ventilation. Crown Copyright 2010. Last accessed $21^{\text {st }}$ August 2011 at http://www.planningportal.gov.uk/uploads/br/BR PDF ADF 2010.pdf.

Hong, H., Shun-cheng, L., Chang-wei, Z., Xin-geng, C., Shao-jia, F., 2007. Characteristics of indoor/outdoor PM2.5 and elemental components in generic urban, roadside and industrial plants areas of Guangzhou City, China. Journal of Environmental Sciences 19, 35-43.

Jones, N.J., Thorton, C.A., Mark, D., Harrison, R. M., 2000. Indoor/outdoor relationships of particulate matter in domestic homes with roadside, urban and rural locations. Atmospheric Environment 34, 6, 2603-2612.

Klepeis, N. E., Nelson, W. C., Ott, W. R., Robinson, J. P., Tsang, a. M., Switzer, P., 2001. The National Human Activity Pattern Survey (NHAPS): a resource for assessing exposure to environmental pollutants. Journal of exposure analysis and environmental epidemiology 11,3, 231-52. doi: 10.1038/sj.jea.7500165.

Lai, H.K., Kendallb, M., Ferriera, H., Lindupc, I., Almd, S., Hanninend, O., Jantunend, M.., Mathyse, P., Colvilea, R.., Ashmoref, M.R.., Cullinang, P., Nieuwenhuijsena, M.J., 2004. Personal exposures and microenvironment concentrations of PM2.5, VOC, NO2 and CO in Oxford, UK. Atmospheric Environment 38, 6399-6410.

LAQN, 2010. London Air Quality Network Last accessed 24 ${ }^{\text {th }}$ June 2011 at http://www.londonair.org.uk/london/asp/datadownload.asp,

LEB, 2011. Low Energy Building Database Last accessed $23^{\text {thd }}$ Jan 2012 at http://retrofitforthefuture.org/

Lomas, K.J., and Eppel, H., 1992. Sensitivity analysis techniques for building thermal simulation programs. Energy and Buildings 19, 21-44.

LAQN, 2010. London Air Quality Network Last accessed 24 ${ }^{\text {th }}$ June 2011 at http://www.londonair.org.uk/london/asp/datadownload.asp,

Macintosh, D.L., Minegishi, T., Kaufman, M., Baker, B.J., Allen, J.G., Levy, J.I., Myatt, T.A., 2010. The benefits of whole-house in-duct air cleaning in reducing exposures to fine particulate matter of outdoor origin: a modeling analysis. Journal of exposure science \& environmental epidemiology 20, 2, 213-224.

Milner, J.T., Dimitroulopoulou, C., ApSimon, H., 2005. Indoor concentrations in buildings from sources outdoors. Report to the UK Atmospheric Dispersion Liaison Committee, Last accessed $11^{\text {th }}$ April 2011 at http://www.admic.org.uk/ar04-05.htm

Molnár, P., Bellander, T., Sällsten, G., Boman, J., 2007. Indoor and outdoor concentrations of PM2.5 trace elements at homes, preschools in Stockholm, Sweden. Journal of Environmental 
Monitoring 4, 348-357.

Mons, U., Nagelhout, G.E., Allwright, S., Guignard, R., Van den Putte, B., Willemsen, M.C., Fong, G.T., Brenner, H., Potschke-Langer, M., and Breitling, L.P.,(in press) Impact of national smoke-free legislation on home smoking bans: findings from the International Control Policy Evaluation Project Europe Surveys.

Olson, D.A., Burke, J.M., 2006. Distributions of PM2.5 source strengths for cooking from the Research Triangle Park particulate matter survey. Environmental Science and Technology 40, 1, 163-169.

ONS, 2000. The Health Survey for England 1996, The Stationery Office, UK.

ONS, 2011. Accommodation Type - Household Spaces (UV56)', last accessed $3^{\text {thd }}$ August 2011 at

http://neighbourhood.statistics.gov.uk/dissemination/LeadTableView.do?a $=3 \& b=276761 \& \mathrm{c}=$ $\mathrm{N} 4+3 \mathrm{BY} \& \mathrm{~d}=13 \& \mathrm{e}=16 \& \mathrm{~g}=339268 \& \mathrm{i}=1001 \times 1003 \times 1004 \& \mathrm{~m}=0 \& \mathrm{r}=0 \& \mathrm{~s}=1312395411164 \& \mathrm{en}$ $\mathrm{C}=1 \&$ dsFamilyld $=149$

Ozkaynak, H., Xue, J., Spenglar, J.D., Wallace, L.A., Pellizzari, E.D., Jenkins, P., 1996. Personal exposure to particles and metals: results from a particle TEAM study in Riverside CA. Journal of Exposure Analysis and Environmental Epidemiology 6, 1, 57-78.

Patra, A., Colvile, R., Arnold, S., Bowen, E., Shallcross, D., Martin, D., Price, C., Tate, J., ApSimon, S., Robins, A., 2008. On street observations of particulate matter movement and dispersion due to traffic on an urban road. Atmospheric Environment 42, 3911-3926.

Ravindra, K., Stranger, M., Van Grieken, R., 2008. Chemical characterization and multivariate analysis of atmospheric PM2.5 particles. Journal of Atmospheric Chemistry 59, 199-218.

Rijal, H.B., Tuohy, P., Humphreys, M.A., Nicol, J.F., Samuel, A., Clarke, J., 2007. Using results from field surveys to predict the effect of open windows on thermal comfort and energy use in buildings. Energy and Building 39, 823-36.

Stephen, R. K., 1998. Airtightness in UK dwellings: BRE test results and their significance', Building Research Establishment, Garston, Watford. BR359. BRE Bookshop, UK.

Thornburg, J. , Ensor, D. S. , Rodes, C. E. , Lawless, P. A., Sparks, L. E., Mosley, R. B., 2001. Penetration of Particles into Buildings and Associated Physical Factors Part I: Model Development and Computer Simulations. Aerosol Science and Technology 34: 3, 284 296,

UKERC, 2009. Making the transition to a secure and low-carbon energy system: synthesis report. Last accessed $22^{\text {nd }}$ June 2011 at http://www.ukerc.ac.uk/Downloads/PDF/09/0904Energy2050report.pdf

Vardoulakis, S., Valiantis, M., Milner, J. and ApSimon, H., 2007. Operational air pollution modelling in the UK - street canyon applications and challenges. Atmospheric Environment 41, 4622-4637.

Vardoulakis, S., Chalabi, Z, Fletcher, T., Grundy, C., Leonardi, G.S., 2008. Impact and uncertainty of a traffic management intervention: Population exposure to Polycyclic Aromatic Hydrocarbons. The Science of the Total Environment 394, 244-251.

Warm Front, 2011. Department of Energy and Climate Change. Last accessed $17^{\text {th }}$ Jan 2012 at http://www.decc.gov.uk/en/content/cms/funding/warm front/warm front.aspx Wallace, L., Williams, R., Rea, A., Croghan, C., 2006. Continuous weeklong measurements of personal exposures and indoor concentrations of fine particles for 37 health impaired North Carolina residents for up to four seasons. Atmospheric Environment 40, 399-414. Weschler, C., 2009. Changes in indoor pollutants since the 1950s. Atmospheric Environment 43, 1, 153-169.

Wilkinson, P., Smith, K.R., Davies, M., Adair, H., Armstrong, B.G., Barrett, M., Bruce, N., Haines, A., Hamilton, I., Oreszczyn, T., Ridley, I., Tonne, C., Chalabi, Z, 2009. Public health benefits of strategies to reduce greenhouse-gas emissions: household energy. The Lancet 374, 9705, 1917-1929

Williams, M.L., 2007. UK air quality in 2050: Synergies with climate change policies. Environmental Science \& Policy 10, 169-175. 